\title{
$\beta$-Amyloid-Stimulated Microglia Induce Neuron Death via Synergistic Stimulation of Tumor Necrosis Factor $\alpha$ and NMDA Receptors
}

\author{
Angela M. Floden, Shanshan Li, and Colin K. Combs \\ Department of Pharmacology, Physiology, and Therapeutics, University of North Dakota, School of Medicine and Health Sciences, Grand Forks, North \\ Dakota 58202
}

\begin{abstract}
Although abundant reactive microglia are found associated with $\beta$-amyloid $(\mathrm{A} \beta)$ plaques in Alzheimer's disease (AD) brains, their contribution to cell loss remains speculative. A variety of studies have documented the ability of A $\beta$ fibrils to directly stimulate microglia in vitro to assume a neurotoxic phenotype characterized by secretion of a plethora of proinflammatory molecules. Collectively, these data suggest that activated microglia play a direct role in contributing to neuron death in $\mathrm{AD}$ rather than simply a role in clearance after plaque deposition. Although it is clear the $\mathrm{A} \beta$-stimulated microglia acutely secrete toxic oxidizing species, the identity of longer-lived neurotoxic agents remains less defined. We used $\mathrm{A} \beta$-stimulated conditioned media from primary mouse microglia to identify more stable neurotoxic secretions. The NMDA receptor antagonists memantine and 2-amino-5-phosphopetanoic acid as well as soluble tumor necrosis factor $\alpha(\mathrm{TNF} \alpha)$ receptor protect neurons from microglial-conditioned media-dependent death, implicating the excitatory neurotransmitter glutamate and the proinflammatory cytokine TNF $\alpha$ as effectors of microglial-stimulated death. Neuron death occurs in an oxidative damage-dependent manner, requiring activity of inducible nitric oxide synthase. Toxicity results from coincident stimulation of the TNF $\alpha$ and NMDA receptors, because stimulations of either alone are insufficient to initiate cell death. These findings suggest the hypothesis that $\mathrm{AD}$ brains provide the appropriate microglial-mediated inflammatory environment for TNF $\alpha$ and glutamate to synergistically stimulate toxic activation of their respective signaling pathways in neurons as a contributing mechanism of cell death.
\end{abstract}

Key words: microglia; TNF $\alpha$; glutamate; NMDA; iNOS; neuron death; inflammation; amyloid; Alzheimer; cytokine

\section{Introduction}

Alzheimer's disease $(\mathrm{AD})$ is characterized by an accumulation of extracellular deposits of $\beta$-amyloid (A $\beta$ ) peptide containing senile plaques and abundant neurofibrillary tangles in the brain (Braak and Braak, 1997). There is extensive evidence that amyloid deposition provokes a microglial-mediated inflammatory response that contributes significantly to the cell loss and cognitive decline that is characteristic of this disease (Akiyama et al., 2000). Amyloid-dependent activation of microglia in vitro results in acquisition of a reactive phenotype and secretion of proinflammatory products, including reactive oxygen species, cytokines, and neurotoxins. However, the identity of the neurotoxic agent(s) generated by reactive microglia experimentally or in AD has not been resolved (Giulian et al., 1995; Ii et al., 1996; Bianca et al., 1999; Combs et al., 2001; Kingham and Pocock, 2001; Xie et al., 2002).

A number of in vitro studies have demonstrated that $\mathrm{A} \beta$ fibril

Received Sept. 1, 2004; revised Jan. 24, 2005; accepted Jan. 24, 2005.

This work was supported by National Institutes of Health (NIH)-National Institute on Aging Grants 1 R03 AG20294-01 and 1 R15 AG16192-01 and by NIH-National Center for Research Resources Grant 1 P20 RR17699-01. We thank Tami Cassavan for expert technical assistance.

Correspondence should be addressed to Dr. Colin K. Combs, Assistant Professor, Department of Pharmacology, Physiology, and Therapeutics, University of North Dakota, School of Medicine and Health Sciences, 501 North Columbia Road, Room 3730, Grand Forks, ND 58202. E-mail: ccombs@medicine.nodak.edu.

DOI:10.1523/JNEUROSCI.4998-04.2005

Copyright $\odot 2005$ Society for Neuroscience $\quad$ 0270-6474/05/252566-10\$15.00/0 stimulation increases microglial tumor necrosis factor $\alpha$ (TNF $\alpha)$ production (Klegeris et al., 1997; Galimberti et al., 1999; Tan et al., 2000; Combs et al., 2001). Although TNF $\alpha$ has been described as a neuronal anti-apoptotic agent (Barger et al., 1995; Gary et al., 1998; Glazner and Mattson, 2000), it is also capable of inducing neuronal death when presented to neurons as part of a glialderived inflammatory milieu (Gelbard et al., 1993; Chao and $\mathrm{Hu}$, 1994; Venters et al., 1999; Combs et al., 2001). The excitatory neurotransmitter, glutamate, is another proinflammatory product secreted by microglia in response to $\mathrm{A} \beta$ fibril stimulation (Klegeris et al., 1997; Noda et al., 1999; Ikezu et al., 2003). It is known that NMDA receptor (NMDAR)-expressing neurons are vulnerable to $\mathrm{AD}$-associated loss, supporting a hypothesis of excitotoxic NMDA receptor activity-mediated death (Greenamyre and Young, 1989; Francis et al., 1993). Encouraging clinical trial data from Alzheimer's patients treated with the noncompetitive NMDA receptor antagonist memantine also supports the idea that NMDA receptor activity is required for disease progression (Jain, 2000; Marx, 2000; Reisberg et al., 2003; Rive et al., 2004; Tariot et al., 2004). Although the effectors of neuron loss remain unclear, data suggest that death may include oxidative damageassociated mechanisms as evidenced by increased neuronal immunoreactivity for inducible nitric oxide synthase (iNOS) and the peroxynitrite marker 3-nitrotyrosine (Vodovotz et al., 1996; Smith et al., 1997; Hensley et al., 1998; Heneka et al., 2001). 
In an effort to link $\mathrm{A} \beta$ fibril deposition with microglial activation and subsequent neuron death, we used an in vitro approach that used $\mathrm{A} \beta$ fibril-stimulated primary mouse microglia and cortical neuron cultures. Our results demonstrate that $A \beta$-activated microglia secrete TNF $\alpha$ and glutamate to synergistically stimulate neuronal iNOS expression and subsequent peroxynitrite production leading to cell death. Cell death requires stimulation with both effectors, because neither alone was able to induce neuron loss. These findings suggest that nontoxic activation of the NMDA receptor can lead to neuronal death in the presence of the appropriate, potentiating, inflammatory stimuli.

\section{Materials and Methods}

Materials. The anti-iNOS (used for Western blot analysis), antiNMDAR1, anti-TNF receptor I (TNFRI), and anti-TNFRII antibodies and protein A-agarose were from Santa Cruz Biotechnology (Santa Cruz, CA). The anti- $\beta$ III tubulin antibody was purchased from Upstate Biotechnology (Charlottesville, VA). Affinity-purified horseradish peroxidase-conjugated secondary antibodies were obtained from Santa Cruz Biotechnology. TNF $\alpha$ and soluble TNFR1 were purchased from R \& D Systems (Minneapolis, MN). Memantine, anti-iNOS antibody (used for immunostaining), anti-nitrotyrosine antibody, 3-morpholinosydnonimine $N$-ethylcarbamide (SIN-1) hydrochloride, the selective non-NMDA receptor antagonist 2,3-dihydroxy-6-nitro-7-sulfonylbenzo[f]quinoxaline (NBQX), and $1400 \mathrm{~W} .2 \mathrm{HCl}$ were from Alexis Biochemicals (Carlsbad, CA). Mn(III)tetrakis(4-benzoic acid) porphyrin (MnTBAP) was purchased from Biomol (Plymouth, PA). The 2-amino5-phosphopetanoic acid (APV), NMDA, glutamate, lipopolysaccharide (LPS), and all other materials not specified were purchased from Sigma (St. Louis, MO).

A $\beta$ fibril preparation. Peptides corresponding to amino acids 1-42 of human $\mathrm{A} \beta$ protein were purchased from American Peptide (Sunnyvale, CA). To fibrillize, $A \beta$ peptides were resuspended in sterile $\mathrm{dH}_{2} \mathrm{O}$ (final concentration, $1 \mathrm{~mm}$ ) followed by incubation for 1 week at $37^{\circ} \mathrm{C}$.

Tissue culture. Neurons were cultured from cortices of embryonic day 16 (E16) mice (C57BL/6). Briefly, meninges-free cortices were isolated, trypsinized, and plated onto poly-L-lysine $(0.05 \mathrm{mg} / \mathrm{ml})$-coated tissue culture wells $\left(260\right.$ cells $\left./ \mathrm{mm}^{2}\right)$ for $7 \mathrm{~d}$ in vitro before use. Neurons were grown in Neurobasal media with L-glutamine and B27 supplements (Invitrogen, Rockville, MD) to consistently provide neuronal cultures $>95 \%$ pure and to survive for at least 1 month in vitro. Culture purity was determined by cell counting after staining with the astrocytic marker anti-glial fibrillary acidic protein and the neuronal marker antimicrotubule-associated protein 2 (MAP2). Microglia were derived from postnatal day 1 (P1) mouse brains (C57BL/6). Briefly, meninges-free cortices from P1 mice were isolated and trypsinized. Cells were plated onto tissue culture plastic in DMEM-F-12 with L-glutamine (Invitrogen) containing $10 \%$ heat-inactivated FBS and 5\% heat-inactivated horse serum and fed every third day. After $\sim 14 \mathrm{~d}$, the cultures were shaken vigorously (30 min; $120 \mathrm{rpm}$ on a rotary shaker) to remove microglia.

Cell stimulation. Microglia were stimulated by removing them from their respective media and plating onto immobilized A $\beta 1-42$ (400 cells/ $\mathrm{mm}^{2} ; 48 \mathrm{~h}$ ) fibrils $\left(48 \mathrm{pmol} / \mathrm{mm}^{2}\right)$. Immobilized peptides were prepared by coating tissue culture wells with nitrocellulose and allowing fibrillar peptides to dry onto the wells. The use of immobilized peptides prevents their subsequent collection in the conditioned medium. After $48 \mathrm{~h}$ of stimulation, microglial-conditioned media were collected, clarified by centrifugation, and added to neuronal cultures with or without vehicle or specific drugs/reagents. Media from wells containing immobilized A $\beta$ peptide alone were collected as a negative control. Neurons were stimulated for $0-72 \mathrm{~h}$. Neurons were fixed and stained using a neuron-specific anti-MAP2 antibody, and a counting grid was placed over the wells to count neuron numbers from four identical fields for each condition. The average number of neurons ( \pm SEM) was calculated for each condition. As neurons die, they retract processes and detach from the dish and are thus removed from viable counts. MAP2-positive cells with visible nuclei and immunostained processes, at least one cell diameter in length, are counted as neurons. Counting-based cell-survival quantitation reliably mirrors other viability measures such as lactate dehydrogenase release or MTT reduction in our hands. To eliminate the confound of contaminating cells contributing to total lactate dehydrogenase release or MTT reduction, we routinely assessed cell survival via counting-based quantitation. Each experiment was performed in quadruplicate three to four times. Values statistically different from controls were calculated using one-way ANOVA. The Tukey-Kramer multiple-comparisons posttest was used to determine $p$ values.

Quantitation of secreted TNF $\alpha$. Conditioned media were taken from microglia after $48 \mathrm{~h}$ of A $\beta\left(48 \mathrm{pmol} / \mathrm{mm}^{2}\right)$ stimulation, and concentrations of secreted TNF $\alpha$ were determined using commercially available mouse TNF $\alpha$ colorimetric sandwich ELISA plates (R \& D Systems).

Western blotting and immunoprecipitation. Neurons were stimulated as described above and then lysed in ice-cold radioimmunoprecipitation assay (RIPA) buffer ( $1 \%$ Triton X-100, 0.1\% SDS, $0.5 \%$ deoxycholate, 20 mм Tris, pH 7.4, $150 \mathrm{~mm} \mathrm{NaCl}, 10 \mathrm{~mm} \mathrm{NaF}, 1 \mathrm{~mm} \mathrm{Na}_{3} \mathrm{VO}_{4}, 1$ mм EDTA, $1 \mathrm{~mm}$ EGTA, and $0.2 \mathrm{M}$ PMSF) and sonicated, and insoluble material was removed by centrifugation $\left(14,000 \mathrm{rpm} ; 10 \mathrm{~min} ; 4^{\circ} \mathrm{C}\right)$. Human brain samples were frozen in liquid nitrogen, pulverized and lysed in RIPA, sonicated, and spun as above. Protein concentrations were quantitated using the method by Bradford (1976). Proteins were resolved by $10 \%$ SDS-PAGE and incubated in primary antibody overnight at $4^{\circ} \mathrm{C}$, followed by incubation in $2^{\circ}$ horseradish peroxidase-conjugated antibody. Antibody binding was detected via enhanced chemiluminescence (Pierce, Rockford, IL).

Immunoprecipitations were performed by incubation of aliquots of the cellular lysates or brain homogenates with the primary antibody (1 $\mu \mathrm{g}$ of antibody $/ \mathrm{mg}$ of protein lysate) overnight at $4^{\circ} \mathrm{C}$ and with protein A-agarose for $2 \mathrm{~h}$ at $4^{\circ} \mathrm{C}$. The immunoprecipitates were washed three times in RIPA buffer and then resolved by 10\% SDS-PAGE and Western blotted as described.

Immunohistochemistry. To perform culture immunohistochemistry, neurons were stimulated as described above and fixed in $4 \%$ paraformaldehyde at $37^{\circ} \mathrm{C}$ for $30 \mathrm{~min}$ at select times. To assess survival, neurons were stained with an anti-MAP2 antibody (Sigma) using Vector VIP (Vector Laboratories, Burlingame, CA) as the chromagen. Culture immunohistochemistry visualizing NMDAR1, TNFRII, and TNFRI was performed using commercial primary antibodies listed above. Antibody binding was visualized using FITC or Texas Red-conjugated $2^{\circ}$ antibodies (Santa Cruz Biotechnology) or Vector VIP. Double-labeling immunocytochemistry visualizing neuronal iNOS was performed using a Zeiss (Thornwood, NY) LSM 510 Meta confocal microscope. Neurons were double labeled using anti-MAP2 antibody and anti-iNOS antibody (Alexis Biochemicals). Sections were mounted in ProLong Gold antifade reagent with 4',6'-diamidino-2-phenylindole (DAPI) (Molecular Probes, Eugene, OR) for imaging.

Nitrite/nitrate assay. To quantitate nitric oxide synthase activity, neurons were removed to antioxidant-free Neurobasal media with B27 supplements (Invitrogen) during stimulations. Media were collected after $72 \mathrm{~h}$ of stimulation, and nitrite/nitrate concentrations were calculated according to manufacturer specifications (Stressgen Biotechnologies, San Diego, CA). To account for cell death in TNF $\alpha /$ NMDA-treated cultures, nitrite/nitrate values were normalized against counted, immunostained neuron number per well. The experiments were performed three times with six repeats per condition and then averaged ( \pm SEM). Values statistically different from controls were calculated using one-way ANOVA. The Tukey-Kramer multiple-comparisons posttest was used to determine $p$ values.

Glutamate quantitation assay. To quantitate glutamate secreted by A $\beta$ stimulated microglia, conditioned media were generated as described above (Cell stimulation). Glutamate concentrations in the collected, clarified media were determined according to manufacturer specification using the commercial glutamate quantitation reagents, Amplex Red Glutamic Acid/Glutamate Oxidase Assay kit (Molecular Probes). The experiments were performed three times with eight repeats per condition and then averaged $( \pm$ SEM). Values statistically different from controls were calculated using one-way ANOVA. The Tukey-Kramer multiplecomparisons posttest was used to determine $p$ values.

Human tissue. Age-matched midtemporal gyrus $\mathrm{AD}$ and control brain 
A

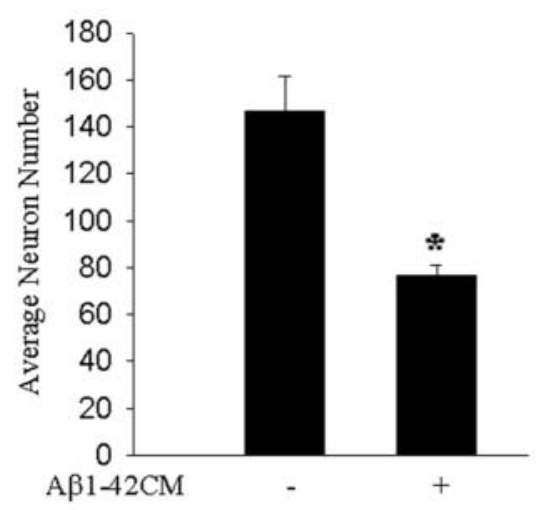

B

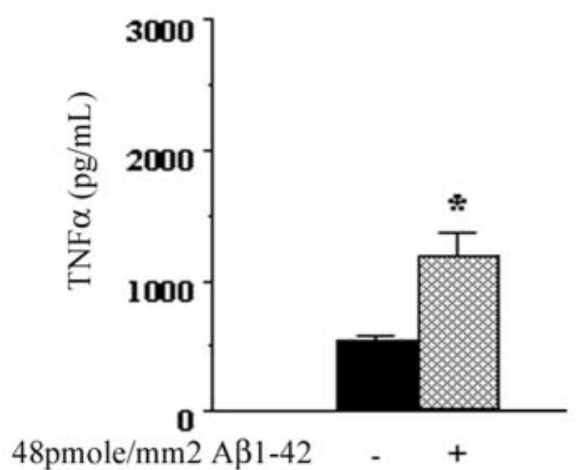

C

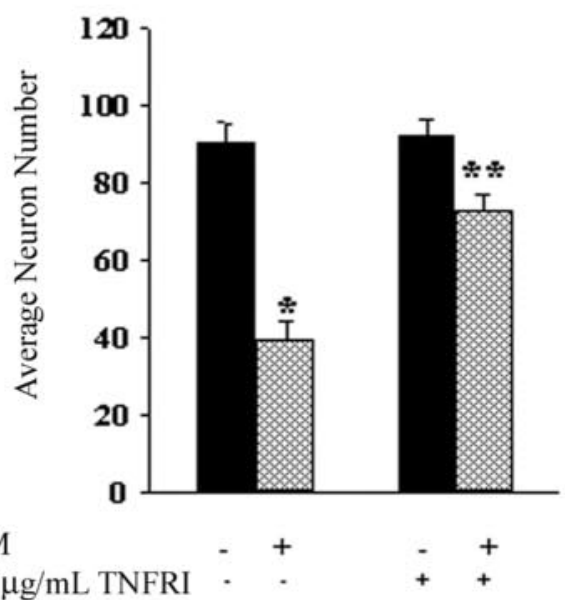

D

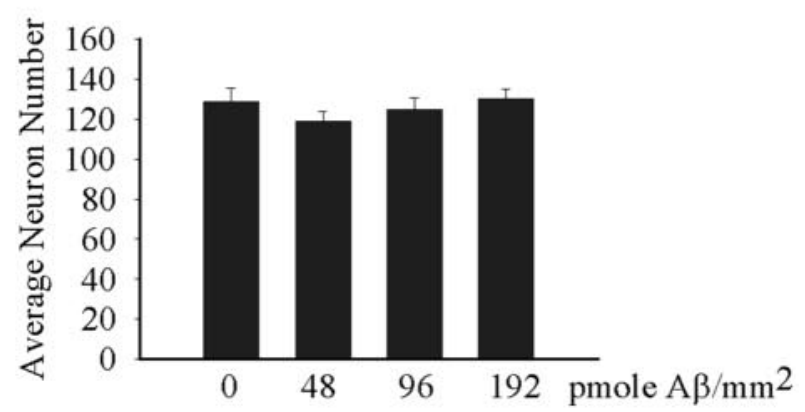

tissue was obtained from Dr. Joseph Rogers (Alzheimer's Disease Core Center, Sun Health Research Institute, Sun City, AZ). Human tissue use was reviewed and approved by the University of North Dakota Institutional Review Board (project IRB-200403-255).

Animal care and use. All procedures were reviewed and approved by the University of North Dakota Institutional Animal Care and Use Committee (protocol 0012-3). Mice were housed at the Center for Biomedical Research on a $12 \mathrm{~h}$ light/dark cycle and were allowed food and water ad libitum. Pregnant mice were killed via $\mathrm{CO}_{2}$ asphyxiation, and embryos were killed via decapitation.

\section{Results}

Proinflammatory secretions from A $\beta$-stimulated microglia stimulate neurotoxicity via stimulation of TNF $\alpha$ and NMDA receptors

We and others have documented that primary mouse microglia and the human THP-1 monocyte cell line respond to fibrillar A $\beta$ peptides by activation of a complex tyrosine kinase-based signaling cascade leading to production of neurotoxic secretory products (McDonald et al., 1997; Combs et al., 1999; Yates et al., 2000). Previous efforts identified the proinflammatory cytokine TNF $\alpha$ as one factor necessary for microglial-conditioned mediadependent death. To begin identifying additional toxic components of the conditioned media, we first considered the possibility that activated microglia secrete glutamate or other NMDA receptor ligands (Giulian et al., 1995; Noda et al., 1999; Guillemin and Brew, 2002; Ikezu et al., 2003). For confirmation, we demonstrated that conditioned media from $\mathrm{A} \beta$-stimulated microglia were potently toxic to mouse cortical neuron cultures (Fig. $1 A$ ). As expected, $\mathrm{A} \beta$ stimulated microglial TNF $\alpha$ secretion (Fig. $1 B$ ), and addition of soluble TNFRI ( $\mathrm{p} 55$ ) to conditioned media provided complete neuroprotection from $\mathrm{A} \beta$-stimulated microglialconditioned media (Fig. 1C). These results extend our previous conclusions using TNF $\alpha$ neutralizing antibodies in the conditioned media (Combs et al., 2001). Importantly, the toxic action of the $A \beta$-stimulated microglial-conditioned media is dependent on microglial secretory products and not contaminating $\beta$-amyloid fibrils (Fig. 1D).

To determine whether NMDA receptor ligands were an additional conditioned media component required for toxicity, we assessed the ability of the activated microglia to secrete glutamate. A number of previous reports have documented the ability of activated microglia to secrete this excitatory neurotransmitter (Barger and Basile, 2001; Ikezu et al., 2003; Nakamura et al., 2003). A $\beta$ stimulation resulted in a significant increase of glutamate secretion into the conditioned media by microglia (Fig. $2 A)$. To verify the contribution of secreted glutamate to condi-

$\leftarrow$

Figure 1. Conditioned media from $A \beta$-stimulated microglia induce neuron death in a TNF $\alpha$-dependent manner. Conditioned Neurobasal media (CM) from primary mouse microglia ( 400 cells $/ \mathrm{mm}^{2}$ ) stimulated for $48 \mathrm{~h}$ with or without (control) immobilized A $\beta 1-42$ fibrils (48 $\mathrm{pmol} / \mathrm{mm}^{2}$ ) was generated. $A$, Control and $A \beta$-stimulated conditioned media were applied to mouse cortical neuron cultures (E16; $7 \mathrm{~d}$ in vitro) for $72 \mathrm{~h}$. Neurons were fixed in $4 \%$ paraformaldehyde, stained using anti-MAP2 antibody, and counted. Neurons from four fields/conditions were counted in quadruplicate wells and averaged \pm SEM. The graph is representative of three independent experiments. $\boldsymbol{B}$, Conditioned media were collected, and TNF $\alpha$ concentrations were determined via commercial ELISA. The graph is representative of three independent experiments. $C$, Cortical neurons were cultured for $72 \mathrm{~h}$ with unstimulated and $A \beta$-stimulated conditioned medium in the absence or presence of soluble TNFRI $(0.1 \mu \mathrm{g} / \mathrm{ml})$. Neurons were fixed, stained using anti-MAP2 antibody, counted as above, and averaged \pm SEM. The graph is representative of three independent experiments. $\boldsymbol{D}$, Media from plates containing increasing concentrations of immobilized $A \beta\left(0,48,96\right.$, and $\left.192 \mathrm{pmol} \mathrm{A} \beta 1-42 / \mathrm{mm}^{2}\right)$ alone were transferred to cortical neurons for $72 \mathrm{~h}$. Neurons were fixed and counted, and statistical significance was determined as above. ${ }^{*} p<0.001$ from control; ${ }^{* *} p<0.001$ from CM. 

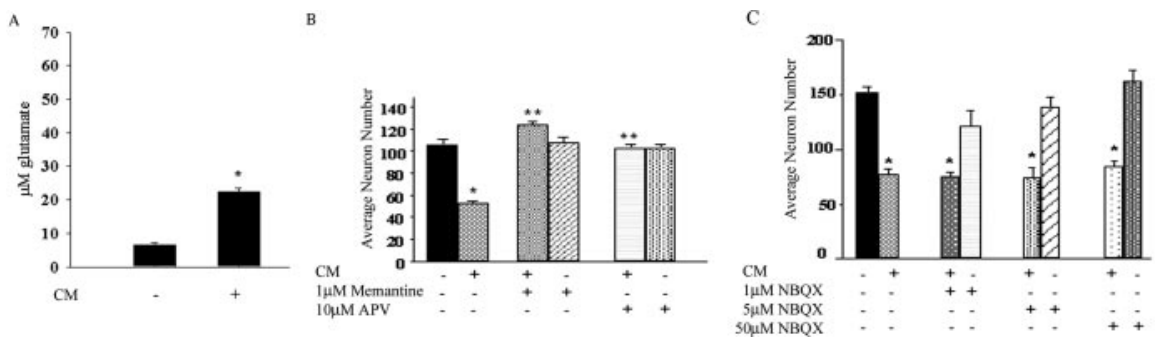

Figure 2. Conditioned media-dependent death requires NMDA receptor activity. $A$, Conditioned Neurobasal media (CM) from primary mouse microglia ( $400 \mathrm{cells} / \mathrm{mm}^{2}$ ) stimulated for $48 \mathrm{~h}$ with or without (control) immobilized A $\beta 1-42$ fibrils ( $48 \mathrm{pmol} /$ $\mathrm{mm}^{2}$ ) were generated, and micromolar glutamate concentrations were calculated from the media. The graph is the average \pm SEM of three independent experiments. Cortical neurons (E16; $7 \mathrm{~d}$ in vitro) were cultured for $72 \mathrm{~h}$ with conditioned medium from primary mouse microglia that were unstimulated or stimulated (CM) $48 \mathrm{~h}$ with A $\beta 1-42$ fibrils in the absence or presence of $1 \mu \mathrm{M}$ memantine and $10 \mu \mathrm{M}$ APV (B) or 1,5, and $50 \mu \mathrm{MNBQX}(\boldsymbol{C})$. Neurons were then fixed, stained using anti-MAP2 antibody, and counted. Neurons from four fields/conditions were counted in quadruplicate wells and averaged \pm SEM. Graphs are representative of three independent experiments. ${ }^{*} p<0.001$ from control; ${ }^{* *} p<0.001$ from CM.

\section{A}

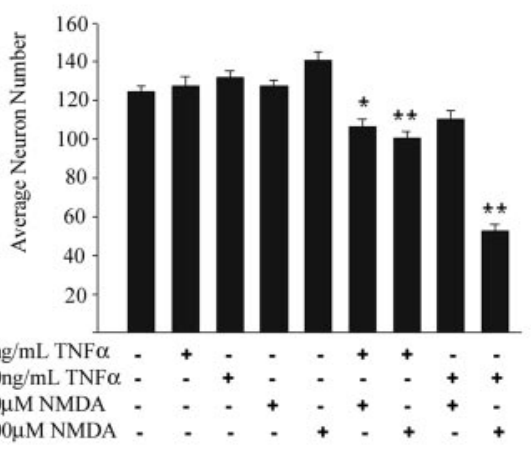

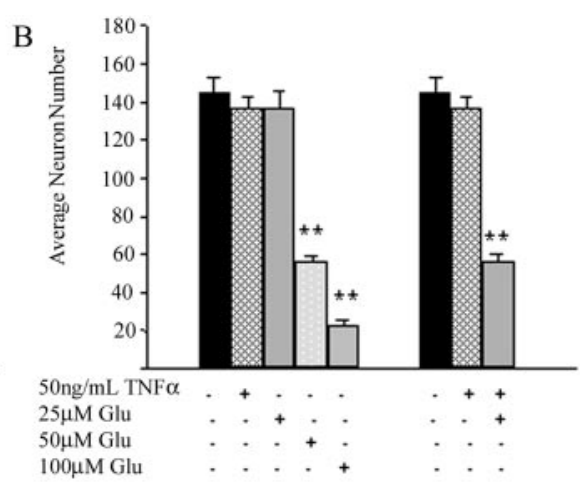

Figure 3. TNF $\alpha$ and glutamate/NMDA synergistically stimulate neuron death. Mouse cortical neurons (E16; $7 \mathrm{~d}$ in vitro) were cultured in the absence or presence of NMDA $(50,100 \mu \mathrm{M})(\boldsymbol{A})$, glutamate $(25,50,100 \mu \mathrm{M})(\boldsymbol{B})$, and mouse TNF $\alpha(5,50 \mathrm{ng} / \mathrm{ml})$. Stimuli were added to neurons for $72 \mathrm{~h}$ and then cells were fixed, stained using anti-MAP2 antibody, and counted. Neurons from four fields/conditions were counted in quadruplicate wells and averaged \pm SEM. Graphs are representative of three independent experiments. ${ }^{*} p<0.05$ from control; ${ }^{* *} p<0.001$ from control.
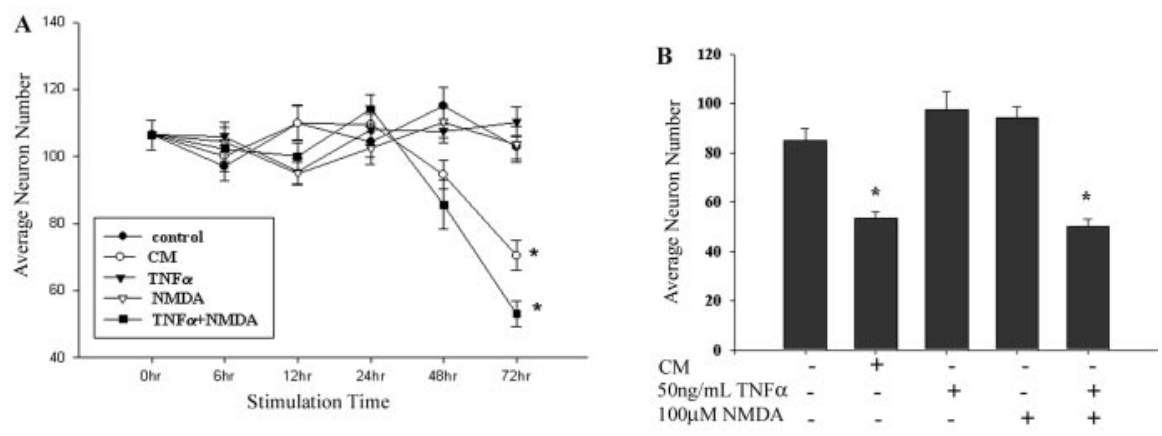

Figure 4. Conditioned media and TNF $\alpha$ plus NMDA-dependent neuron death have a similar time course. Mouse cortical neurons (E16; $7 \mathrm{~d}$ in vitro) were cultured in the absence or presence of conditioned medium from microglia that were unstimulated or stimulated (CM) $48 \mathrm{~h}$ with A $\beta 1-42$ fibrils, NMDA $(100 \mu \mathrm{m})$, and mouse TNF $\alpha(50 \mathrm{ng} / \mathrm{ml})$. A, Stimuli were added to neurons for $0-72 \mathrm{~h}$. At select time points, cells were fixed, stained, and counted. $\boldsymbol{B}$, Alternatively, stimuli were added to neurons for $1 \mathrm{~h}$ and then replaced with fresh media and fixed after a total time of $72 \mathrm{~h}$. Neurons from four fields/conditions were counted in quadruplicate wells and averaged \pm SEM. Graphs are representative of three independent experiments. ${ }^{*} p<0.001$ from control.

tioned media-stimulated death, the noncompetitive NMDA receptor antagonist memantine or the competitive NMDA receptor antagonist APV was added to the media after addition to the neurons (Davies et al., 1981; Bormann, 1989). Both reagents provided complete protection demonstrating that NMDA receptor activation is a component of the conditioned media-stimulated death (Fig. 2 B). Consistent with this observation, the competitive quisqualate receptor antagonist NBQX offered no protection from the conditioned media-mediated toxicity (Sheardown et al., 1990) (Fig. 2C). Nevertheless, to avoid activation of multiple glutamate receptor subtypes, subsequent experiments typically used NMDA instead of glutamate.

Recombinant TNF $\alpha$ and NMDA induce neurotoxicity similar to conditioned media from $\mathrm{A} \boldsymbol{\beta}$-stimulated microglia

The conditioned media experiments identified both glutamate and TNF $\alpha$ as components required for neurotoxicity. To determine whether these stimuli alone were sufficient to induce conditioned mediadependent type death, neurons were treated with mouse recombinant TNF $\alpha$ and NMDA or glutamate. Both NMDA (Fig. 3A) and glutamate (Fig. 3B) induced neuron death in a dose-dependent manner when added to neurons in the presence of TNF $\alpha$. Importantly, stimulation with TNF $\alpha$ alone had no affect on viability (Fig. $3 A$ ). Doses of glutamate and NMDA needed to induce the synergistic death with $\mathrm{TNF} \alpha$ were sufficiently low, to prevent direct excitotoxicity, and consistent with our quantitated values from conditioned media. Neuron loss induced by microglial-conditioned media or $\mathrm{TNF} \alpha$ and NMDA displayed a prolonged time course occurring between 24 and $72 \mathrm{~h}$, suggesting a similar mechanism (Fig. 4A). Importantly, a transient $1 \mathrm{~h}$ stimulation with conditioned media or $\mathrm{TNF} \alpha$ and NMDA was sufficient to induce neuron loss by $72 \mathrm{~h}$, demonstrating that neuronal death was rapidly initiated despite the delayed time course of loss (Fig. 4B).

\section{Simultaneous TNF $\alpha$ and NMDA} stimulation induces neuron death in a manner requiring inducible nitric oxide synthase activity and peroxynitrite formation

We previously demonstrated that microglial-conditioned media induce neuron death in a manner requiring increased expression and activity of iNOS (Combs et al., 2001). Increased iNOS activity can facilitate the reaction of nitric oxide with superoxide anion to form the strong oxidizing and protein tyrosine nitrating agent peroxynitrite (Beckman et al., 1992; Ischiropoulos et al., 1992). Our previous work demonstrated that increased iNOS activity in conditioned media-treated cultures stimulated increased peroxynitrite formation as determined by increased levels of protein nitration (Combs et al., 2001). To confirm that TNF $\alpha$ and NMDA receptor stimulation induced death via an identical mechanism, we compared the abilities of the iNOS-selective inhibitor $1400 \mathrm{~W} .2 \mathrm{HCl}$ and the superoxide dismutase mimetic and per- 
oxynitrite scavenger MnTBAP to protect neurons from conditioned media (Fig. 5A) and synergistic TNF $\alpha$ and NMDA (Fig. 5B) stimulation (Garvey et al., 1997; Zingarelli et al., 1997; Klann, 1998; Day et al., 1999). Addition of $1400 \mathrm{~W}$ as well as MnTBAP was sufficient to protect neurons from TNF $\alpha$ and NMDA-dependent death.

Correspondingly, TNF $\alpha$ and NMDA treatment stimulated increased iNOS protein levels and activity (Fig. 6A,B) as well as increased protein nitration (Fig. $7 A$ ) within treated neurons. Importantly, treatment of neuronal cultures with the peroxynitrite donor SIN-1 produced a qualitatively similar increase in protein nitrotyrosine levels (Fig. 7B) (Hogg et al., 1992). These data verified that TNF $\alpha$ and NMDA-mediated death shares mechanism with conditioned media-dependent death involving increased iNOS expression and activity. A mechanism of iNOS/peroxynitrite-mediated death in AD is correlatively supported by the observation of increased iNOS protein levels and protein tyrosine nitration in $\mathrm{AD}$ brains compared with age-matched controls (Figs. 6C, 7C).

Although neuronal iNOS immunoreactivity has been reported previously (Heneka et al., 2003; Grange-Messent et al., 2004; Rodrigo et al., 2004; Small et al., 2004), its expression is certainly well documented in glia as well (Xie et al., 2002; Dehmer et al., 2004; Iravani et al., 2004; Morale et al., 2004; Wang et al., 2004). To confirm that our iNOS-mediated death was occurring via neuronally generated nitric oxide, we performed immunohistochemistry to determine which cell types in our culture were expressing iNOS. It is difficult to eliminate completely all contaminating cell types from the cultures, and the presence of contaminating astrocytes or microglia could have been responsible for our observed iNOS effects. Double labeling of our cultures after treatment with $\mathrm{TNF} \alpha$ and NMDA demonstrated a robust increase in iNOS immunolabeling that was localized within MAP2-expressing neuronal cells (Fig. 8). These data confirmed that the stimulation was responsible for increasing protein levels of neuronal iNOS.

\section{Specific neurons coexpress NMDA and TNF receptors in vitro} NMDA receptors are heteromers comprised of multiple subunits, and receptor activity properties are determined primarily by the composition of specific NMDAR2 isoforms (Monyer et al., 1992; Zhang et al., 1994; Boeckman and Aizenman, 1996; Monaghan and Larsen, 1997). Similarly, the TNF $\alpha$-dependent signaling response is dependent on the specific receptor isoform, TNFRI (p55) or TNFRII (p75), involved (Natoli et al., 1998). To characterize NMDA and TNF $\alpha$ receptor isoform expression in our neuron cultures, Western blot analysis was performed at $7 \mathrm{~d}$ in vitro before stimulation. Western blot analysis demonstrated neuronal expression of p55 TNFRI and low-level expression of p75 TNFRII along with the ubiquitous R1 subunit of the NMDA receptor (Fig. 9A). Immunohistochemical analysis verified that neurons display heterogeneous levels of NMDAR1 immunoreactivity that colocalizes with TNFR1 and TNFRII immunoreactivity (Fig. 9B). These results support our conclusion that synergistic stimulation of these receptors is responsible for a cross-talk response leading to neuron death.
B

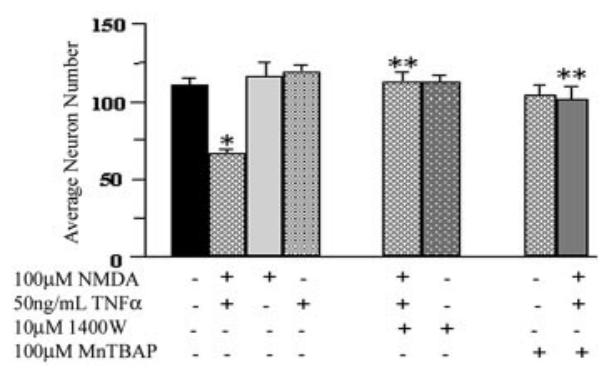

$+$

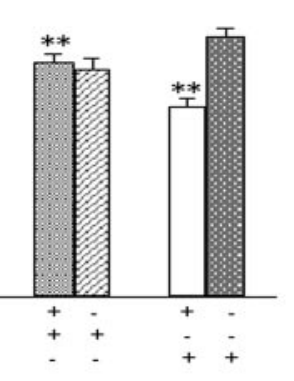

Figure 5. Conditioned media and TNF $\alpha$ plus NMDA-dependent neuron death both involve iNOS activity and peroxynitrite
formation. Mouse cortical neurons (E16;7 d in vitro) were cultured in the absence or presence of conditioned medium from primary mouse microglia that were unstimulated or stimulated (CM) $48 \mathrm{~h}$ with A $\beta 1-42$ fibrils, NMDA (100 $\mu \mathrm{M})$, and mouse TNF $\alpha$ (50 $\mathrm{ng} / \mathrm{ml})$. $\boldsymbol{A}$, Conditioned media were added to neurons in the absence or presence of $100 \mu \mathrm{m} \mathrm{MnTBAP} \mathrm{or} 10 \mu \mathrm{m} 1400 \mathrm{~W} .2 \mathrm{HCl}$. $\boldsymbol{B}$ stimulated for $72 \mathrm{~h}$ and then fixed, stained, and counted. Neurons from four fields/conditions were counted in quadruplicate wells and

\section{Discussion}

Our results indicate that $\mathrm{A} \beta$-stimulated microglia secrete TNF $\alpha$ and glutamate to synergistically induce neuron death requiring iNOS activity and peroxynitrite production. Cell death required stimulation with both ligands, because neither alone at the doses used was sufficient to induce neuron loss. Based on our findings, we propose the hypothesis that $\mathrm{A} \beta$-activated microglia secrete TNF $\alpha$ and glutamate to initiate a signaling cross-talk response capable of converting two innocuous stimuli into one promoting oxidative damage-associated neuron death. It is encouraging that other microglial-mediated inflammatory neurodegenerative paradigms, ventricular LPS infusion and hippocampal A $\beta$ injection, have been shown previously to involve NMDA receptordependent neuron death (Willard et al., 2000; Miguel-Hidalgo et al., 2002). Additionally, it has been reported that microglial activation in vitro with secreted amyloid precursor protein or LPS also results in neuron death in a manner involving NMDA receptor activity as well as nitric oxide synthesis (Kim and Ko, 1998; Barger and Basile, 2001). Collectively, these results suggest that microglial control of extracellular glutamate concentrations is an important proinflammatory response in addition to classically described cytokine and reactive oxygen/nitrogen species secretion (Rimaniol et al., 2000).

Although we propose a role for TNF $\alpha$ potentiation of NMDA receptor-dependent death, previous studies have characterized an ability of TNF $\alpha$ to provide neuroprotection (Barger et al., 1995; Houzen et al., 1997; Mattson et al., 1997; Carlson et al., 1999; Kaltschmidt et al., 1999; Keller et al., 1999; Glazner et al., 2000; Diem et al., 2001; Viel et al., 2001; Bruce-Marchetti et al., 2004). Importantly, some of these neuroprotective paradigms have demonstrated TNF $\alpha$ protection against NMDA-mediated death in apparent contrast to our findings (Houzen et al., 1997; Furukawa and Mattson, 1998). One possibility for this discrepancy could be a result of differences in expression levels of NMDA or TNF $\alpha$ receptors. We and others have observed that expression of NMDA and TNF $\alpha$ receptors is dependent on culture age, culture density, and the presence of contaminating glia (Daniels and Brown, 2001; Church and Hewett, 2003) (data not shown). Previous culture protocols contained an apparently higher number of glia than ours, and the culture age and neuronal plating density used also differ (Houzen et al., 1997; Furukawa and Mattson, 1998). In this study, we sought to determine direct effects of TNF $\alpha$ and NMDA receptor stimulation on neurons 
A

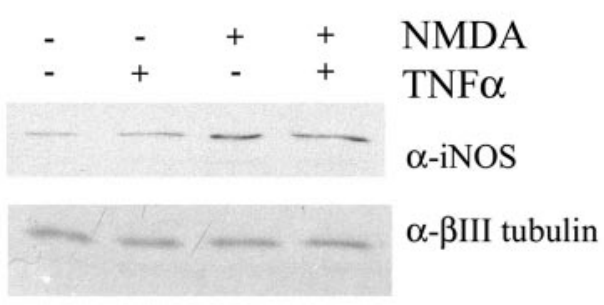

B

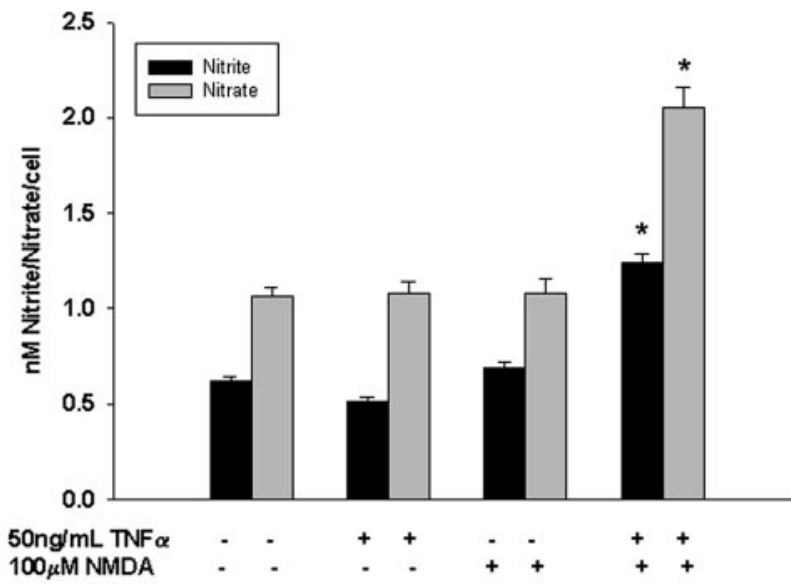

$\mathrm{C}$
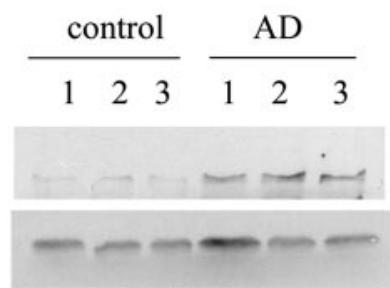

$\alpha-\mathrm{iNOS}$

$\alpha-\beta$ III tubulin

Figure 6. TNF $\alpha$ plus NMDA-dependent neuron death stimulates increased iNOS protein levels and activity. Neurons were unstimulated or stimulated $72 \mathrm{~h}$ with TNF $\alpha(50 \mathrm{ng} / \mathrm{ml}), 100$ $\mu$ NMDA, or TNF $\alpha$ plus NMDA. $A$, To determine iNOS protein levels, neurons were lysed, and proteins were resolved by $10 \%$ SDS-PAGE and Western blotted using rabbit anti-iNOS antibody. Antibody binding was visualized by enhanced chemiluminescence. Lysates were blotted with antibody recognizing neuron-specific $\beta$ III tubulin as a protein-loading control. Blots are representative of four independent experiments. $\boldsymbol{B}$, To assess nitric oxide synthase, activity concentrations of nitrite and nitrate in neuronal media were quantitated after $72 \mathrm{~h}$ of stimulation with TNF $\alpha$, NMDA, or TNF $\alpha$ plus NMDA. Nitrite/nitrate concentrations were normalized to cell number and averaged from six repeats per condition from three independent experiments $\left({ }^{*} p<\right.$ 0.001 compared with respective control). C, Proteins from three AD and three control brain midtemporal gyrus homogenates were separated by $10 \%$ SDS-PAGE and Western blotted using rabbit anti-iNOS antibody. Antibody binding was visualized by enhanced chemiluminescence. Lysates were blotted with antibody recognizing neuron-specific $\beta$ III tubulin as a proteinloading control.

rather than determine cell-cell mechanisms invoked in mixed cultures. For this reason, we used a nearly pure population of neurons at a defined age and density to make our observations. We have shown direct neuronal expression of NMDA receptors colocalizing with both TNFRI and TNFRII at $7 \mathrm{~d}$ in vitro, supporting our hypothesis that we are observing direct effects of TNF $\alpha$ and NMDA on neurons. Therefore, our system allows future opportunity to dissect neuronal intracellular signaling cross talk between the cytokine and NMDA receptors. Certainly, the in vitro nature of our system implies the possibility that both NMDA and TNF $\alpha$ receptors may operate differently in vivo. However, the concentrations of NMDA used are within typical in vitro experimental concentrations, and TNF $\alpha$ concentrations are in the physiologic range (Floyd and Krueger, 1997; Furukawa and Mattson, 1998).
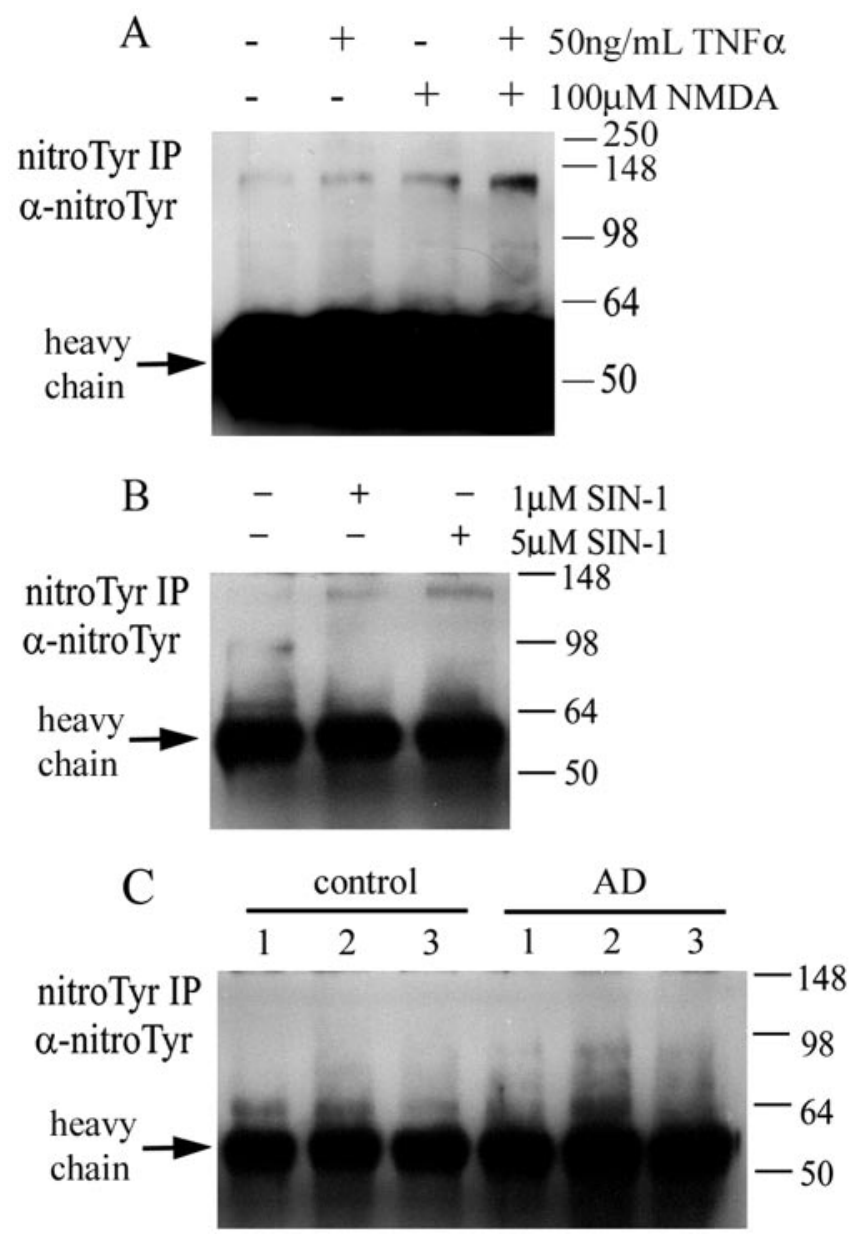

Figure 7. TNF $\alpha$ plus NMDA-dependent neuron death stimulates increased protein nitrotyrosine levels. Neurons were unstimulated or stimulated $72 \mathrm{~h}$ with TNF $\alpha(50 \mathrm{ng} / \mathrm{ml}), 100 \mu \mathrm{m}$ NMDA, TNF $\alpha$ plus NMDA, or 1 and $5 \mu \mathrm{M}$ SIN-1. A, To determine nitrotyrosine protein levels, neurons were lysed, and proteins were immunoprecipitated and resolved by 10\% SDS-PAGE and Western blotted using mouse anti-nitrotyrosine antibodies. Antibody binding was visualized by enhanced chemiluminescence. Blots are representative of four independent experiments. $\boldsymbol{B}$, To assess SIN-1-dependent protein, nitration cells were lysed, and nitrated proteins were immunoprecipitated, resolved by $10 \%$ SDS-PAGE, and blotted with anti-nitrotyrosine antibody. C, Nitrotyrosine-containing proteins were immunoprecipitated from midtemporal gyrus homogenate from three AD and three control brain samples and separated by $10 \%$ SDSPAGE and Western blotted using anti-nitrotyrosine antibody. Antibody binding was visualized by enhanced chemiluminescence. IgG heavy chain is identified (arrows) on the blots simply for orientation purposes.

We noted that subpopulations of neurons in our cultures colocalize TNFRI or TNFRII with the NMDAR1 subunit of the NMDA receptor. It will be important to determine whether a specific NMDA receptor subunit or TNF $\alpha$ receptor isoform expression/subcellular colocalization identifies neurons for death. NMDA receptor subunit composition appears to regulate susceptibility to NMDA-dependent death (Sinor et al., 2000). Additionally, previous in vivo work has demonstrated TNFRI and TNFRII mediating neurotoxic and neurotrophic stimulations, respectively (Yang et al., 2002). Identifying the TNF $\alpha$ receptormediating signaling cross talk with a specific subunit containing NMDA receptor may provide mechanisms to explain the well documented paradoxical role of this cytokine in vivo in contributing to both neurodegeneration and neurorepair during inflammation-associated conditions (Stoll et al., 2000; Saha and Pahan, 2003). 

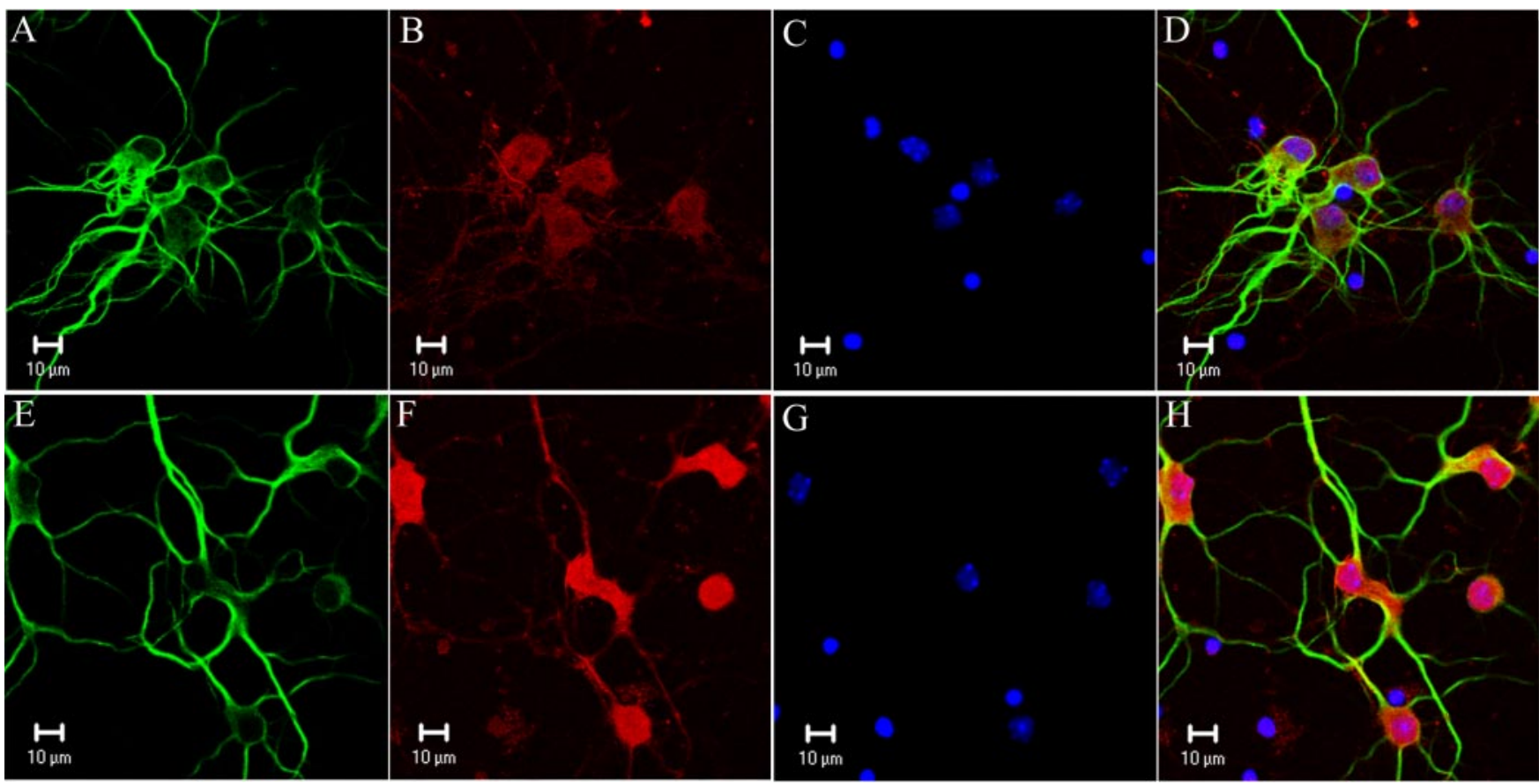

Figure 8. TNF $\alpha$ plus NMDA induces increased neuronal iNOS immunoreactivity. Neurons were unstimulated $(\boldsymbol{A}-\boldsymbol{D})$ or stimulated $(\boldsymbol{E}-\boldsymbol{H}) 72 \mathrm{~h}$ with TNF $\alpha(50 \mathrm{ng} / \mathrm{ml})$ plus $100 \mu \mathrm{m} \mathrm{NMDA}$ and then fixed in 4\% paraformaldehyde. Cultures were double labeled using anti-MAP2 and anti-iNOS antibodies with FITC and Texas Red-conjugated secondary antibodies, respectively. Cultures were mounted in DAPI containing mounting media for confocal imaging. $\boldsymbol{A}, \boldsymbol{E}$, Anti-MAP2; $\boldsymbol{B}, \boldsymbol{F}$, anti-iNOS; $\boldsymbol{C}, \boldsymbol{G}, \mathrm{DAPI} ; \boldsymbol{D}$, merge of $\boldsymbol{A}-\boldsymbol{C} ; \boldsymbol{H}$, merge of $\boldsymbol{E}-\boldsymbol{G}$. Images are representative of three independent experiments.

A

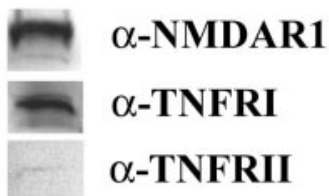

B

\section{Q-NMDAR1}
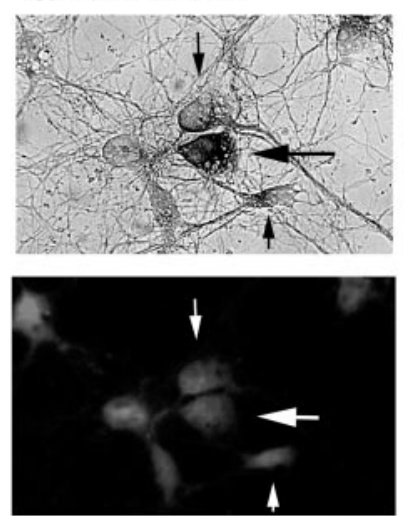

$\alpha$-TNFRI
$\alpha$-NMDAR1
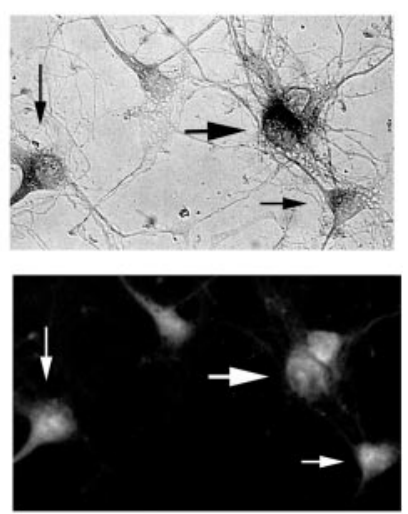

$\alpha$-TNFRII

Figure 9. Neuronal NMDAR subunit immunoreactivity colocalizes with TNFRI and TNFRII. Cortical neuron cultures from E16 mice were cultured for $7 \mathrm{~d}$ in vitro and then collected in RIPA buffer. $\boldsymbol{A}$, Lysates were resolved by $10 \%$ SDS-PAGE and Western blotted using antibodies recognizing NMDAR1, TNFRI, and TNFRII. Antibody binding was visualized via enhanced chemiluminescence. $\boldsymbol{B}$, Neurons were fixed at $7 \mathrm{~d}$ in vitro and dually immunostained using anti-TNFRI/ TNFRII and anti-NMDAR1 antibodies. Primary antibody binding was visualized using Texas Red-conjugated anti-rabbit and FITC-conjugated anti-goat antibodies for TNFRI and TNFRII, respectively, and Vector VIP for NMDAR1. Arrows demonstrate examples of varying levels of immunoreactivity for each antigen.

The final effector of the iNOS-dependent death we describe is likely peroxynitrite formation and oxidation of target molecules, including DNA and proteins (Radi et al., 1991; King et al., 1993). Our demonstration of a typical peroxynitrite decomposition ratio, larger concentrations of nitrate $\left(\mathrm{NO}_{3}{ }^{-}\right)$than nitrite $\left(\mathrm{NO}_{2}{ }^{-}\right)$, in the neuronal media suggests the generation of peroxynitrite (Pfeiffer et al., 1997). The oxidative capacity of this molecule is assumed mostly to be responsible for its neurotoxicity. Indeed, our neuroprotection provided by selective iNOS inhibitors as well as radical scavenging reagents supports this idea. We chose to limit our study to characterize toxicity because of relatively longlived species in the microglial-conditioned media. This allowed us to describe neuronal production of oxidizing/nitrating species in response to a defined stimulation of microglial-secreted TNF $\alpha$ and glutamate. However, it is probable that several cell types as well as additional molecules contribute to neuronal death in vivo during similar inflammatory events. For example, astrocytes and microglia are also very effective at generating damaging oxidizing/nitrating species (Xie et al., 2002; Dehmer et al., 2004; Iravani et al., 2004; Morale et al., 2004; Wang et al., 2004). In vivo or during glia-neuron coculture paradigms, $\mathrm{A} \beta$-activated glia can certainly generate labile oxidizing species that contribute acutely to the resultant neuronal death (Xie et al., 2002). Therefore, to completely determine specific cellular generation and contribution of oxidizing species to neuronal death, future experiments will require in vivo disease modeling.

The coincident stimulation-induced neuron death identified from our microglial-mediated inflammation paradigm can help to understand a potential mechanism of neuron death occurring in $\mathrm{AD}$ brains. It has been suggested from both in vivo histological studies as well as in vitro work that $\mathrm{A} \beta$ plaque-associated microglia directly contribute to neuron loss in $\mathrm{AD}$ via release of a plethora of neurotoxic products in a number of different paradigms (Akiyama et al., 2000). We identified a specific mechanism by 
which two secretory products from $\mathrm{A} \beta$-activated microglia can directly lead to oxidative damage-dependent death. We predict that neurons that coexpress specific TNF $\alpha$ and NMDA receptors in human adult brain are susceptible to the particular inflammation-associated death we describe. More importantly, the specific cellular localization of TNF $\alpha$ receptor subtypes with certain NMDA receptor subunits may identify vulnerable neuronal populations in the $\mathrm{AD}$ brain. In correlative support of this hypothesis, it is known that levels of TNF $\alpha$ and neuronal TNFRI expression in the AD brain are elevated (Fillit et al., 1991; Bruunsgaard et al., 1999; Tarkowski et al., 1999; Zhao et al., 2003), and NMDA receptor-expressing neurons represent a population vulnerable for loss during disease (Greenamyre and Young, 1989; Francis et al., 1993). Additionally, neurons in the AD brain display increased immunoreactivity for both iNOS and tyrosine-nitrated proteins similar to our in vitro observations (Figs. 6, 8) (Vodovotz et al., 1996; Smith et al., 1997; Hensley et al., 1998). The microglial-mediated death mechanism we observed may provide specific molecular targets amenable to targeting for neuroprotective therapeutic design. For example, the success of the noncompetitive NMDA receptor antagonist, memantine, for treatment of $\mathrm{AD}$ patients supports the idea that NMDA receptor activity is required for disease progression (Jain, 2000; Marx, 2000; Reisberg et al., 2003; Rive et al., 2004; Tariot et al., 2004). Finally, it is conceivable that the inflammationassociated death we characterized may be mechanistically important for neuron loss in a variety of inflammation-associated neurodegenerative conditions besides $\mathrm{AD}$.

\section{References}

Akiyama H, Barger S, Barnum S, Bradt B, Bauer J, Cole GM, Cooper NR, Eikelenboom P, Emmerling M, Fiebich BL, Finch CE, Frautschy S, Griffin WS, Hampel H, Hull M, Landreth G, Lue L, Mrak R, Mackenzie IR, McGeer PL, et al. (2000) Inflammation and Alzheimer's disease. Neurobiol Aging 21:383-421.

Barger S, Basile AS (2001) Activation of microglia by secreted amyloid precursor protein evokes release of glutamate by cystine exchange and attenuates synaptic function. J Neurochem 76:846-854.

Barger SW, Hortser D, Furukawa K, Goodman Y, Krieglstein J, Mattson MP (1995) Tumor necrosis factors alpha and beta protect neurons against amyloid beta-peptide toxicity: evidence for involvement of a kappa B-binding factor and attenuation of peroxide and $\mathrm{Ca}^{2+}$ accumulation. Proc Natl Acad Sci USA 92:9328-9332.

Beckman J, Ischiropoulos H, Zhu L, van der Woerd M, Smith C, Chen J, Harrison J, Martin J, Tsai M (1992) Kinetics of superoxide dismutaseand iron-catalyzed nitration of phenolics by peroxynitrite. Arch Biochem Biophys 298:438-445.

Bianca VD, Dusi S, Bianchini E, Dal Pra I, Rossi F (1999) Beta-amyloid activates the O-2 forming NADPH oxidase in microglia, monocytes, and neutrophils. A possible inflammatory mechanism of neuronal damage in Alzheimer's disease. J Biol Chem 274:15493-15499.

Boeckman FA, Aizenman E (1996) Pharmacological properties of acquired excitotoxicity in Chinese hamster ovary cells transfected with $\mathrm{N}$-methylD-aspartate receptor subunits. J Pharmacol Exp Ther 279:515-523.

Bormann J (1989) Memantine is a potent blocker of $N$-methyl-D-aspartate (NMDA) channels. Eur J Pharmacol 166:591-592.

Braak H, Braak E (1997) Frequency of stages of Alzheimer-related lesions in different age categories. Neurobiol Aging 18:351-357.

Bradford MM (1976) A rapid and sensitive method for the quantitation of microgram quantities of protein utilizing the principle of protein-dye binding. Anal Biochem 72:248-254.

Bruce-Keller AJ, Geddes JW, Knapp PE, McFall RW, Keller JN, Holtsberg FW, Parthasarathy S, Steiner SM, Mattson MP (1999) Anti-death properties of TNF against metabolic poisoning: mitochondrial stabilization by MnSOD. J Neuroimmunol 93:53-71.

Bruunsgaard H, Andersen-Ranberg K, Jeune B, Pedersen AN, Skinhoj P, Pedersen BK (1999) A high plasma concentration of TNF-alpha is asso- ciated with dementia in centenarians. J Gerontol A Biol Sci Med Sci 54: M357-M364.

Carlson NG, Wieggel WA, Chen J, Bacchi A, Rogers SW, Gahring LC (1999) Inflammatory cytokines IL-1 alpha, IL-1 beta, IL-6, and TNF-alpha impart neuroprotection to an excitotoxin through distinct pathways. J Immunol 163:3963-3968.

Chao CC, Hu S (1994) Tumor necrosis factor-alpha potentiates glutamate neurotoxicity in human fetal brain cell cultures. Dev Neurosci 16:172-179.

Church WH, Hewett SJ (2003) Relationship between NMDA receptor expression and MPP + toxicity in cultured dopaminergic cells. J Neurosci Res 73:811-817.

Combs CK, Johnson DE, Cannady SB, Lehman TM, Landreth GE (1999) Identification of microglial signal transduction pathways mediating a neurotoxic response to amyloidogenic fragments of $\beta$-amyloid and prion proteins. J Neurosci 19:928-939.

Combs CK, Karlo JC, Kao S-C, Landreth GE (2001) $\beta$-Amyloid stimulation of microglia and monocytes results in TNF $\alpha$-dependent expression of inducible nitric oxide synthase and neuronal apoptosis. J Neurosci 21:1179-1188

Daniels M, Brown DR (2001) Astrocytes regulate N-methyl-D-aspartate receptor subunit composition increasing neuronal sensitivity to excitotoxicity. J Biol Chem 276:22446-22452.

Davies J, Francis AA, Jones AW, Watkins JC (1981) 2-Amino-5phosphonovalerate (2APV), a potent and selective antagonist of amino acid-induced and synaptic excitation. Neurosci Lett 21:77-81.

Day BJ, Batinic-Haberle I, Crapo JD (1999) Metalloporphyrins are potent inhibitors of lipid peroxidation. Free Radic Biol Med 26:730-736.

Dehmer T, Heneka MT, Sastre M, Dichgans J, Schulz JB (2004) Protection by pioglitazone in the MPTP model of Parkinson's disease correlates with I kappa B alpha induction and block of NF kappa B and iNOS activation. J Neurochem 88:494-501.

Diem R, Meyer R, Weishaupt JH, Bahr M (2001) Reduction of potassium currents and phosphatidylinositol 3-kinase-dependent AKT phosphorylation by tumor necrosis factor- $\alpha$ rescues axotomized retinal ganglion cells from retrograde cell death in vivo. J Neurosci 21:2058-2066.

Fillit H, Ding WH, Buee L, Kalman J, Altstiel L, Lawlor B, Wolf-Klein G (1991) Elevated circulating tumor necrosis factor levels in Alzheimer's disease. Neurosci Lett 129:318-320.

Floyd RA, Krueger JM (1997) Diurnal variation of TNF alpha in the rat brain. NeuroReport 8:915-918.

Francis PT, Simms NR, Proctor AW, Bowen DM (1993) Cortical pyramidal neuron loss may cause glutamatergic hypoactivity and cognitive impairment in Alzheimer's disease-investigative and therapeutic perspectives. J Neurochem 60:1589-1604.

Furukawa K, Mattson MP (1998) The transcription factor NF-kappaB mediates increases in calcium currents and decreases in NMDA- and AMPA/ kainate-induced currents induced by tumor necrosis factor-alpha in hippocampal neurons. J Neurochem 70:1876-1886.

Galimberti D, Baron P, Meda L, Prat E, Scarpini E, Delgado R, Catania A, Lipton JM, Scarlato G (1999) Alpha-MSH peptides inhibit production of nitric oxide and tumor necrosis factor-alpha by microglial cells activated with beta-amyloid and interferon gamma. Biochem Biophys Res Commun 263:251-256.

Garvey EP, Oplinger JA, Furfine ES, Kiff RJ, Laszlo F, Whittle BJ, Knowles RG (1997) $1400 \mathrm{~W}$ is a slow, tight binding, and highly selective inhibitor of inducible nitric-oxide synthase in vitro and in vivo. J Biol Chem 272:4959-4963.

Gary DS, Bruce-Keller AJ, Kindy MS, Mattson MP (1998) Ischemic and excitotoxic brain injury is enhanced in mice lacking the p55 tumor necrosis factor receptor. J Cereb Blood Flow Metab 18:1283-1287.

Gelbard HH, Dzenko KA, DiLoreto D, del Cerro C, del Cerro M, Epstein LG (1993) Neurotoxic effects of tumor necrosis factor alpha in primary human neuronal cultures are mediated by activation of the glutamate AMPA receptor subtype: implications for AIDS neuropathogenesis. Dev Neurosci 15:417-422.

Giulian D, Haverkamp LJ, Li J, Karshin WL, Yu J, Tom D, Li X, Kirkpatrick JB (1995) Senile plaques stimulate microglia to release a neurotoxin found in Alzheimer's brain. Neurochem Int 27:119-137.

Glazner GW, Mattson MP (2000) Differential effects of BDNF, ADNF9, and TNFalpha on levels of NMDA receptor subunits, calcium homeostasis, and neuronal vulnerability to excitotoxicity. Exp Neurol 161:442-452. 
Grange-Messent V, Raison D, Dugas B, Calas A (2004) Noradrenaline upregulates the neuronal and the inducible nitric oxide synthase isoforms in magnocellular neurons of rat brain slices. J Neurosci Res 78:683-690.

Greenamyre JT, Young AB (1989) Excitatory amino acids and Alzheimer's disease. Neurobiol Aging 10:593-602.

Guillemin GJ, Brew BJ (2002) Implications of the kynurenine pathway and quinolinic acid in Alzheimer's disease. Redox Rep 7:199-206.

Heneka MT, Wiesinger H, Dumitrescu-Ozimek L, Riederer P, Feinstein DL, Klockgether T (2001) Neuronal and glial coexpression of arginosuccinate synthetase and inducible nitric oxide synthase in Alzheimer Disease. J Neuropathol Exp Neurol 60:906-916.

Heneka MT, Gavrilyuk V, Landreth GE, O’Banion MK, Weinberg G, Feinstein DL (2003) Noradrenergic depletion increases inflammatory responses in brain: effects on IkappaB and HSP70 expression. J Neurochem 85:387-398.

Hensley K, Maidt ML, Yu Z, Sang H, Markesbery WR, Floyd RA (1998) Electrochemical analysis of protein nitrotyrosine and dityrosine in the Alzheimer brain indicates region-specific accumulation. J Neurosci 18:8126-8132.

Hogg N, Darley-Usmar VM, Wilson MT, Moncada S (1992) Production of hydroxyl radicals from the simultaneous generation of superoxide and nitric oxide. Biochem J 281:419-424.

Houzen H, Kikuchi S, Kanno M, Shinpo K, Tashiro K (1997) Tumor necrosis factor enhancement of transient outward potassium currents in cultured rat cortical neurons. J Neurosci Res 50:990-999.

Ii M, Sunamoto M, Ohnishi K, Ichimori Y (1996) $\beta$-Amyloid proteindependent nitric oxide production from microglial cells and neurotoxicity. Brain Res 720:93-100.

Ikezu T, Luo X, Weber GA, Zhao J, McCabe L, Buescher JL, Ghorpade A, Zheng J, Xiong H (2003) Amyloid precursor protein-processing products affect mononuclear phagocyte activation: pathways for sAPP- and A $\beta$-mediated neurotoxicity. J Neurochem 85:925-934.

Iravani MM, Liu L, Rose S, Jenner P (2004) Role of inducible nitric oxide synthase in $\mathrm{N}$-methyl-D-aspartic acid-induced strio-nigral degeneration. Brain Res 1029:103-113.

Ischiropoulos H, Zhu L, Beckman J (1992) Peroxynitrite formation from macrophage-derived nitric oxide. Arch Biochem Biophys 298:446-451.

Jain KK (2000) Evaluation of memantine for neuroprotection in dementia. Expert Opin Invest Drugs 9:1397-1406.

Kaltschmidt B, Uherek M, Wellmann H, Volk B, Kaltschmidt C (1999) Inhibition of NF-kappaB potentiates amyloid beta-mediated neuronal apoptosis. Proc Natl Acad Sci USA 96:9409-9414.

Kim W-K, Ko KH (1998) Potentiation of N-methyl-D-aspartate-mediated neurotoxicity by immunostimulated murine microglia. J Neurosci Res 54:17-26.

King PA, Jamison E, Strahs D, Anderson VE, Brenowitz M (1993) "Footprinting" proteins on DNA with peroxonitrous acid. Nucleic Acids Res 21:2473-2478.

Kingham PJ, Pocock JM (2001) Microglial secreted cathepsin B induces neuronal apoptosis. J Neurochem 76:1475-1484.

Klann E (1998) Cell-permeable scavengers of superoxide prevent long-term potentiation in hippocampal area CA1. J Neurophysiol 80:452-457.

Klegeris A, Walker DG, McGeer PL (1997) Regulation of glutamate in cultures of human monocytic THP-1 and astrocytoma U-373 MG cells. J Neuroimmunol 78:152-161.

Marchetti L, Klein M, Schlett K, Pfizenmaier K, Eisel UL (2004) Tumor necrosis factor (TNF)-mediated neuroprotection against glutamate-induced excitotoxicity is enhanced by $N$-methyl-D-aspartate receptor activation: essential role of a TNF receptor 2-mediated phosphatidylinositol 3-kinase dependent NF-\{kappa\}B pathway. J Biol Chem 279:32869-32881.

Marx J (2000) Alzheimer's congress. Drug shows promise for advanced disease. Science 289:375-377.

Mattson MP, Goodman Y, Luo H, Fu W, Furukawa K (1997) Activation of $\mathrm{NF}-\kappa \mathrm{B}$ protects hippocampal neurons against oxidative stress-induced apoptosis: evidence for induction of manganese superoxide dismutase and suppression of peroxynitrite production and protein tyrosine nitration. J Neurosci Res 49:681-697.

McDonald DR, Brunden KR, Landreth GE (1997) Amyloid fibrils activate tyrosine kinase-dependent signaling and superoxide production in microglia. J Neurosci 17:2284-2294.

Miguel-Hidalgo JJ, Alvarez XA, Cacabelos R, Quack G (2002) Neuroprotec- tion by memantine against neurodegeneration induced by beta-amyloid (1-40). Brain Res 958:210-221.

Monaghan DT, Larsen H (1997) NR1 and NR2 subunit contributions to $\mathrm{N}$-methyl-D-aspartate receptor channel blocker pharmacology. J Pharmacol Exp Ther 280:614-620.

Monyer H, Sprengel R, Schoepfer R, Herb A, Higuchi M, Lomeli H, Burnashev N, Sakmann B, Seeburg PH (1992) Heteromeric NMDA receptors: molecular and functional distinction of subtypes. Science 256:1217-1221.

Morale MC, Serra PA, Delogu MR, Migheli R, Rocchitta G, Tirolo C, Caniglia S, Testa N, L'Episcopo F, Gennuso F, Scoto GM, Barden N, Miele E, Desole MS, Marchetti B (2004) Glucocorticoid receptor deficiency increases vulnerability of the nigrostriatal dopaminergic system: critical role of glial nitric oxide. FASEB J 18:164-166.

Nakamura Y, Ohmaki M, Murakami K, Yoneda Y (2003) Involvement of protein kinase $\mathrm{C}$ in glutamate release from cultured microglia. Brain Res 962:122-128.

Natoli G, Costanzo A, Guido F, Moretti F, Levrero M (1998) Apoptotic, non-apoptotic, and anti-apoptotic pathways of tumor necrosis factor signaling. Biochem Pharmacol 56:915-990.

Noda M, Nakanishi H, Akaike N (1999) Glutamate release from microglia via glutamate transporter is enhanced by amyloid-beta peptide 92:1465-1474.

Pfeiffer S, Gorren AC, Schmidt K, Werner ER, Hansert B, Bohle DS, Mayer B (1997) Metabolic fate of peroxynitrite in aqueous solution. Reaction with nitric oxide and $\mathrm{pH}$-dependent decomposition to nitrite and oxygen in a 2:1 stoichiometry. J Biol Chem 272:3465-3470.

Radi R, Beckman JS, Bush KM, Freeman BA (1991) Peroxynitrite oxidation of sulfhydryls. The cytotoxic potential of superoxide and nitric oxide. J Biol Chem 2667:4244-4250.

Reisberg B, Doody R, Stoffler A, Schmitt F, Ferris S, Mobius HJ (2003) Memantine in moderate-to-severe-Alzheimer's disease. N Eng J Med 348:1333-1341

Rimaniol AC, Haik S, Martin M, Le Grand R, Boussin FD, DereuddreBosquet N, Gras G, Dormont D (2000) $\mathrm{Na}^{+}$-dependent high-affinity glutamate transport in macrophages. J Immunol 164:5430-5438.

Rive B, Vercelletto M, Damier FD, Cochran J, Francois C (2004) Memantine enhances autonomy in moderate to severe Alzheimer's disease. Int J Geriatr Psychiatry 19:458-464.

Rodrigo J, Fernandez-Vizarra P, Castro-Blanco S, Bentura ML, Nieto M, Gomez-Isla T, Martinez-Murillo R, MartInez A, Serrano J, Fernandez AP (2004) Nitric oxide in the cerebral cortex of amyloid-precursor protein (SW) Tg2576 transgenic mice. Neuroscience 128:73-89.

Saha RN, Pahan K (2003) Tumor necrosis factor-alpha at the crossroads of neuronal life and death during HIV-associated dementia. J Neurochem 86:1057-1071.

Sheardown MJ, Nielsen EO, Hansen AJ, Jacobsen P, Honore T (1990) 2,3Dihydroxy-6-nitro-7-sulfamoyl-benzo(F)quinoxaline: a neuroprotectant for cerebral ischemia. Science 247:571-574.

Sinor JD, Du S, Venneti S, Blitzblau RC, Leszkiewicz DN, Rosenberg PA, Aizenman E (2000) NMDA and glutamate evoke excitotoxicity at distinct cellular locations in rat cortical neurons in vitro. J Neurosci 20:8831-8837.

Small CI, Lyles GA, Breen KC (2004) Inducible form of nitric oxide synthase expression in rat cortical neuronal cells in vitro. Neurobiol Dis 17:70-76.

Smith MA, Richey Harris PL, Sayre LM, Beckman JS, Perry G (1997) Widespread peroxynitrite-mediated damage in Alzheimer's disease. J Neurosci 17:2653-2657.

Stoll G, Jander S, Schroeter M (2000) Cytokines in CNS disorders: neurotoxicity versus neuroprotection. J Neural Transm Suppl 59:81-89.

Tan J, Town T, Mori T, Wu Y, Saxe M, Crawford F, Mullan M (2000) CD45 opposes $\beta$-amyloid peptide-induced microglial activation via inhibition of p44/42 mitogen-activated protein kinase. J Neurosci 20:7587-7594.

Tariot PN, Farlow MR, Grossberg GT, Graham SM, McDonald S, Gergel I (2004) Memantine treatment in patients with moderate to severe Alzheimer disease already receiving donepezil: a randomized controlled trial. JAMA 291:317-324.

Tarkowski E, Blennow K, Wallin A, Tarkowski A (1999) Intracerebral production of tumor necrosis factor-alpha, a local neuroprotective agent, in Alzheimer disease and vascular dementia. J Clin Imunol 19:223-230.

Venters HD, Tang Q, Liu Q, VanHoy RW, Dantzer R, Kelley KW (1999) A 
new mechanism of neurodegeneration: a proinflammatory cytokine inhibits receptor signaling by a survival peptide. Proc Natl Acad Sci USA 96:9879-9884.

Viel JJ, McManus DQ, Smith SS, Brewer GJ (2001) Age- and concentrationdependent neuroprotection and toxicity by TNF in cortical neurons from $\beta$-amyloid. J Neurosci Res 64:454-465.

Vodovotz Y, Lucia MS, Flanders KC, Chesler L, Xie QW, Smith TW, Weidner J, Mumford R, Webber R, Nathan C, Roberts AB, Lippa CF, Sporn MB (1996) Inducible nitric oxide synthase in tangle-bearing neurons of patients with Alzheimer's disease. J Exp Med 184:1425-1433.

Wang Q, Rowan MJ, Anwyl R (2004) $\beta$-Amyloid-mediated inhibition of NMDA receptor-dependent long-term potentiation induction involves activation of microglia and stimulation of inducible nitric oxide synthase and superoxide. J Neurosci 24:6049-6056.

Willard LB, Hauss-Wegrzyniak B, Danysz W, Wenk GL (2000) The cytotoxicity of chronic neuroinflammation upon basal forebrain cholinergic neurons of rats can be attenuated by glutamatergic antagonism or cyclooxygenase-2 inhibition. Exp Brain Res 134:58-65.

Xie Z, Wei M, Morgan TE, Fabrizio P, Han D, Finch CE, Longo VD (2002)
Peroxynitrite mediates neurotoxicity of amyloid $\beta$-peptide 1-42- and lipopolysaccharide-activated microglia. J Neurosci 22:3484-3492.

Yang L, Lindholm K, Konishi Y, Li R, Shen Y (2002) Target depletion of distinct tumor necrosis factor receptor subtypes reveals hippocampal neuron death and survival through different signal transduction pathways. J Neurosci 22:3025-3032.

Yates SL, Burgess LH, Kocsis-Angle J, Antal JM, Dority MD, Embury PB, Piotrkowski AM, Brunden KR (2000) Amyloid beta and amylin fibrils induce increases in proinflammatory cytokine and chemokine production by THP-1 cells and murine microglia. J Neurochem 74:1017-1025.

Zhang L, Zheng X, Paupard MC, Wang AP, Santchi L, Friedman LK, Zukin RS, Bennett MV (1994) Spermine potentiation of recombinant $\mathrm{N}$-methyl-D-aspartate receptors is affected by subunit composition. Proc Natl Acad Sci USA 91:10883-10887.

Zhao M, Cribbs DH, Anderson AJ, Cummings BJ, Su JH, Wasserman AJ, Cotman CW (2003) The induction of the TNFalpha death domain signaling pathway in Alzheimer's disease brain. Neurochem Res 28:307-318.

Zingarelli B, Day BJ, Crapo JD, Salzman AL, Szabo C (1997) The potential role of peroxynitrite in the vascular contractile and cellular energetic failure in endotoxic shock. Br J Pharmacol 120:259-267. 